\title{
Leadership and Development in Postcolonial Africa: The cases of Botswana, Somalia and Somaliland
}

\author{
Nancy Adimora*
}

\begin{abstract}
Scholars have routinely identified weak and ineffective institutions as the root cause of underdevelopment across Africa. Such findings, which place emphasis on 'institutional systems' and 'state mechanisms', too often neglect the critical leadership dimensions of development challenges. Whilst the scientific study of leadership is commonly associated with organisational behaviour, a venture beyond scholarly guidelines reveals how leadership finds relevance at all levels of social interaction. The study of postcolonial nation building is amongst the finest ways to assess the interconnectedness of leadership and development. At government infancy, where there are no systems or state institutions to speak of, a group of elite individuals occupy a space to which the process of leadership is enacted to its greatest potential. In order to interrogate this further, this article focuses primarily on Botswana and Somalia; two countries conveniently positioned on either end of Africa's development spectrum.
\end{abstract}

\section{Introduction}

Scholars have routinely identified weak and ineffective institutions as the root cause of underdevelopment across Africa. Such findings, which place emphasis on 'institutional systems' and 'state mechanisms', too often neglect the critical leadership dimensions of development challenges. Whilst the scientific study of leadership is commonly associated with organisational behaviour, a venture beyond scholarly guidelines reveals how leadership finds relevance at all levels of social interaction.

The study of postcolonial nation building is amongst the finest ways to assess the interconnectedness of leadership and development. At government infancy, where there are no systems or state institutions to speak of, a group of elite individuals occupy a space to which the process of leadership is enacted to its greatest potential. In order to interrogate this further, this article focuses primarily on Botswana and Somalia; two countries conveniently positioned on either end of Africa's development spectrum.

Indeed, critics can cite Botswana's discovery and exploitation of diamonds in the early 1970 s as a means of nullifying the validity of this comparative study. By 
disregarding trade economics and focusing solely on social development, this study hopes to bypass such criticism. Far removed from capitalist agendas, a rather simple, albeit contentious, definition of development will be adopted: Development is tantamount to 'Living Well and Living Long'. ${ }^{1}$ The outward simplicity of this definition shrouds the reoccurring issue of relativism. Though 'living well' can be captured at the level of the individual, complexities start to emerge when applied to groups of diverse people occupying and interacting within the same space. This is often linked to the culturally rich continent of Africa. The civil war in Nigeria, the genocide in Rwanda, and the post-election violence in Kenya, has led a number of commentators to conclude that tribalism is the root cause of Africa's turbulent history. ${ }^{2}$ Yet, as Samatar explains, social fragmentation is not a product of tribal animosity, it is a product of ineffective management of competing interests. ${ }^{3}$ This is where leadership comes into play.

In order to further interrogate this idea, one's conception of leadership must transcend a mere exploration of personality traits. Instead, it is necessary to engage with the works of new-age leadership scholars who claim that trait-based leadership studies amounts to very little without a rational understanding of the situation at hand. ${ }^{4}$ Their argument is simple; leadership does not hinge on 'charisma' or 'oratorical skills', leadership is based on an interactive process. First, the situation that a group of people confront creates a particular kind of need, the nature of this need ultimately determines who will emerge as a leader, and finally, the response to this need can consequently be used to measure leadership effectiveness.

On the basis of this, it will be shown that Botswana and Somalia began on a rather level playing field; confronting similar issues of societal disintegration in the immediate post-independence period. Concluding with a review of Somaliland, this article will systematically exonerate tribalism of all culpability, demonstrating that leadership is ultimately responsible for promoting collective interests, or exacerbating vulnerability. ${ }^{5}$

Breaking down the leadership process into clear identifiable stages, this study adopts a formulaic approach, looking at (1) the situation, (2) leadership emergence, (3) leadership moments, and (4) the leader-follower influence

\footnotetext{
${ }^{1}$ Olonisakin, Funmi (2015) 'Reconceptualising Leadership for Effective Peacemaking in Africa', Strategic Review of Southern Africa, Vol. 37 No.1, May 2015, pp. 122-151

2 For example, see 'How Tribalism Stunts African Democracy', BBC News, November 2012

${ }^{3}$ Samatar, Abdi Ismail (1997) 'Leadership and Ethnicity in the Making of African State Models: Botswana versus Somalia', Third World Quarterly, Vol. 18, No. 4, pp. 687-707, p. 687

${ }^{4}$ See Stogdill, Ralph M. (1948) 'Personal factors associated with leadership: A survey of the literature', Journal of Psychology, 25, p.35-71. Also see, See, Northouse, Peter G. (2013) Leadership: Theory and Practice, Sixth Edition (Western University Press), pp. 30-32

${ }^{5}$ Samatar (1997), p. 688
} 
exchange, before finally reflecting on (5) the outcome. This article shall contend that:

1. Mohammed Siad Barre's ineffective use of Position power was characterised by an outright failure to manage conversations about how Somalis could pursue their individual and collective development agendas.

2. Conversely, Seretse Khama's astute use of Personal power was tantamount to true leadership; his effective management of societal idiosyncrasies meant he was able to successfully navigate Botswana towards a communal goal of a 'living well and living long'.

3. Community Elders in Somaliland illustrate that Somalia's failure and Botswana's success were not coincidental. Instead, the leadership styles adopted by key individuals went on to shape the diametrically opposed development trajectories of these respective countries.

In assessing historical leadership pitfalls, this study does not attempt to conduct a post-mortem of the failures Africa has faced as a continent. One can only hope to promulgate the idea that once scholars accept the increasing interconnectedness between leadership and social cohesion, one can perhaps begin to uncover the leadership typology most conducive to successful development processes going forward.

\section{Somalia: Siad Barre, Positon Power and Unity at all costs}

When it is not metaphorically deployed to indicate profound destruction, or at the brunt of 'dodgy passport' jokes, Somalia is summarily accused of being a haven of outright corruption and terrorist activity. To illustrate this, a BBC reporter deemed

'Mogadishu', Somalia's capital city, an appropriate adjective to describe the perilous scenes in London during the 2011 riots. ${ }^{6}$ Such realities illuminate the story of this plagued region. Following the demise of the government in 1991, and the subsequent years of internal conflict, Somalia has ceased to exist as a coherent political entity. This is perhaps more concerning in light of the fact that Somalia became the first contemporary African country in which a peaceful and constitutional transfer of presidential power took place. ${ }^{7}$ In spite of this glowing historical fact, it is difficult to find a country that has struggled more profoundly with instituting even the basic structures of governance. A venture into the

\footnotetext{
${ }^{6}$ Harper, Mary (2012), Getting Somalia Wrong? Faith and War in a Shattered State, African Arguments (Zed Books), p.1

${ }^{7}$ Samatar (1997), p. 701
} 
history of the afflicted nation and the leadership at the time does much to elucidate our understanding of the splintered patchwork of semi-autonomous regions which remain today.

\section{The Situation}

It is in some ways surprising that Somalia is so dysfunctional as a modern 'nation-state'. Unlike most other African countries, it is not torn apart by tribalism, it is almost unique in Sub-Saharan Africa in that the vast majority of the population shares the same language, ethnicity, culture and religion. It is ironic that the main other example of such a homogenous African country is Botswana, one of the continent's most successful states. ${ }^{8}$

Scholars willing to foray into Somalia's cultural landscape will almost certainly use the term 'homogenous' in an attempt to highlight how Somalia possesses the basic ingredients for a cohesive nation. Lewis talks of the 'single ethnic unity' of the Cushitic-speaking family, whilst Cassanelli narrates the 'strong sense of national identity' felt amongst Somalis. ${ }^{9}$ Yet, as Ahmed and Green note, these examinations of the supposed uniqueness of the Somali people as a culturally homogenous entity are reductionist generalisations that ignore the intricacies of Somalia's socio-political reality. ${ }^{10}$

In actual fact, Somali society has always been divided into nomadic pastoralists in the north and agro-pastoralists in the south; each with distinctively different cultural and social structures, as well as disparate experiences under British and Italian colonial rule. ${ }^{11}$ Whilst Somalia's profound instability partly stems the incongruous state structures imposed during the colonial era, it can also be found in the clan structures which traditionally played a substantial role in the pastoral lives of Somalis. ${ }^{12}$

\footnotetext{
${ }^{8}$ Harper (2012), p. 10

${ }^{9}$ See, Lewis, I.M. (1981) Somali Culture, History, and Social Institutions: An Introductory Guide to the Somali Democratic Republic (London School of Economics \& Political Science), p.1. See also Cassanelli, Lee V. (1982), The Shaping of Somali Society: Reconstructing the History of a Pastoral People, 1600 to 1900 (University of Pennsylvania Press), p. 3

${ }^{10}$ Ahmed, Ismail I., and Green, Reginald Herbold (1999), 'The Heritage of War and State

Collapse in Somalia and Somaliland: Local-Level Effects, External Interventions and

Reconstruction', Third World Quarterly, Vol. 20, No. 1, Complex Political Emergencies, pp. 113-127, p. 114

${ }^{11}$ Ahmed and Green (1999), p. 114

12 For detailed background of Somalia during colonial era, see 'SOMALIA, A Government at War With Its Own People, Testimonies about the Killings and The Conflict in the North', An Africa Watch Report, January 1990, pp. 13-30
} 
The importance of clan associations cannot be over emphasised; this historic social structure continues to form the bedrock of Somali life. Geoff Loane, a relief coordinator for Somalia for the Red Cross, once remarked that 'life is lived and death is died by clan', whilst Aisha Mariam, a community worker in Hargeisa, described the clan as the 'centre of the Somali universe', determining everything about them. ${ }^{13}$ In a nomadic society in which individuals maintained no fixed address, clan allegiance was the most important form of identification. ${ }^{14} \mathrm{~A}$ child unable to recite his clan lineage (abtirsiinyo) through the male line was summarily labelled as ignorant as the entirety of their being, their social standing, their relatives and friends, is determined by this mode of social grouping. ${ }^{15}$ Yet, whilst this means of identification unites based on commonalities, it also naturally highlights group differences and so continues to play an inherently divisive role in Somali society. This is demonstrated clearly through the popular Somali proverb:

Me and my clan against the world;

Me and my family against my clan;

Me and my brother against my family;

Me against my brother. ${ }^{16}$

This speaks to Ahmed and Green's summary dismissal of Somalia's supposed ethnic homogeneity. It can be argued that commonalities such as language and religion are insufficient indicators for determining ethnic groupings. One therefore has to be careful to distinguish between the external and internal lens. For many, ethnicity is a feeling of shared origins and mutual lived experiences; it is one's own way of self-conception and identification to which the perception of the 'us' and the 'other' exists towards other ethnicities. ${ }^{17}$

So, whilst the succession of freely elected democratic governments, the flourishing parliamentary system, and the independent judiciary appeared to indicate that the new republic was a quaint success, this triumph only existed at surface level. When political scientist Ali Mazrui remarked that Somalia came 'close to being the most open society in post-colonial Africa', he did so with little consideration of the all-pervasive element in Somali politics; the loyalty of the

\footnotetext{
13 See, Perlez, Jane (1992), 'Barrier to Somali Unity: Clan Rivalry', The New York Times, and Harper (2012), p. 36

14 Brown, Fraser (1993), 'Tragedy in Somalia: Clans, Colonisers, Superpowers, and the Cult of Personality', Origins, p. 10

15 Drysdale, John (1964), The Somali Dispute (London: Pall Mall Press), p. 8

16 Harper (2012), p. 11

17 Brothers, Sue and Hermans, Janet, and Nteta, Doreen (1993), Botswana in The 21 ${ }^{\text {st }}$ Century: Proceeding of a Symposium, Organised by The Botswana Society (Gaborone, Botswana), p. 375
} 
individual to his kin and clan..$^{18}$ Despite the perceived patriotic fervour which acclaimed the formation of the Republic, clan frictions and stark distinctions between the two former colonies continued to undermine the superficial construction of the Somali State.

In 1969, 1,002 candidates from 62 parties contested 123 seats in the National Assembly. ${ }^{19}$ Outwardly, this system of proportional representation could denote nothing more than establishment of a dynamic and lively parliamentary democracy in the new republic. Yet, when the overwhelming number of candidates and political parties were each representing a particular clan, or subclan, this hotly contest election only worked to exacerbate socio-political tensions. ${ }^{20}$ With a population of only 5 million, 62 parties was an indication of a bitter and divisive electoral atmosphere. The clan-affiliated political parties had discredited the multi-party system and undermined the centralized parliamentary regime. The result of interparty bickering and allegations of corruption was increasing instability, mounting public disquiet and anxiety amongst the civilian population.

Needless to say then, that the primary situation confronting Somalia in the 1960s was that of failed unification. Amongst society, there was a perception that the civilian multi-party system was inherently weak, indecisive and open to manipulation by dominant clans. ${ }^{21}$ The perceived inefficiency and misuse of the political system by politicians for selfish economic ends heightened disillusionment towards this centralised system and threatened to undo the work of the colonial powers. Whilst many bought into the idea of a greater Somalia, they required an individual or a group of individuals to effectively manage the space and balance competing notions of living long and living well. This was the situation; this was the call for a new, distinctive form of leadership.

\section{Leader Emergence}

The lack of familiarity with the complexities inherent in a foreign democratic system created an unbridgeable disconnect between governance and the varied needs of Somalia. Somalia required a new form of government, one tailor-made to suit the unique requirements of the new Republic. Mohamed Siad Barre was the individual who answered this call. The assassination of President Shermarke

\footnotetext{
${ }^{18}$ Lewis, I.M. (1988), A Modern History of Somalia: Nation and State in the Horn of Africa, Revised, updated and Expanded Edition (Westview Press, Boulder \& London), p.166 and Harper (2012), p. 53

${ }^{19}$ Harper (2012), p. 53

20 'SOMALIA, A Government at War With Its Own People, Testimonies About The Killings and The Conflict in the North', An Africa Watch Report, January 1990, p. 14

${ }^{21}$ Ibid, p. 14
} 
provided the optimum conditions for leadership emergence. Though Shermarke's death was not politically motivated, it created a political vacuum; one which was summarily filled in the early hours of 21 October 1969. As the national assembly dithered over Shermarke's successor, Barre, the head of a 25member Supreme Revolutionary Council (SRC) pioneered a bloodless coup to become the Commander-in-Chief of the armed forces. ${ }^{22}$

\section{Leadership Moment}

It is crucial to note that leadership is an active response to a situation. It is not to be, it is to do; a verb, not an adjective. Therefore, when considering leadership, one must think of it as moments or events captured in a particular space and time. Though Barre implemented a number of policies and reforms during his presidency, this section will focus solely on his response to the issue of social discord. In an attempt to extinguish clan alliances, Barre opted to promulgate socialism throughout Somalia.

Owing to the training exercises he underwent as the Vice Commander of Somalia's Army in the early 1960s, Barre spent an extended period of time with Soviet officers, gaining exposure to the of Soviet-style Marxist government of the time. ${ }^{23}$ Swept away by their strong sense of nationalism, Barre soon became an advocate of socialism and unilaterally took the decision to promulgate this radical idea of 'sharing' across the splintered factions throughout Somalia. On the first anniversary of the coup, in October 1970, the Second Charter of the Revolution declared Somalia a socialist state. Barre announced that the doctrine of "Scientific Socialism" was to be the ideology of the reformed government, and the basis for its economic, social and political program.

The doctrine of Scientific Socialism was now the cornerstone of official policy and closely related to the newly proclaimed ideals of 'togetherness'. ${ }^{24}$ Barre was not deterred by the fact that the country had no history of class conflict as he managed to serendipitously couple Marxist ideals with the denunciation of tribalism. As the official slogan went, 'Tribalism divides, Socialism unites'. ${ }^{25}$

'Tribalism and nationalism cannot go hand in hand. It is unfortunate that our nation is rather too clannish: if all Somalis are to go to Hell, tribalism will be their vehicle to get there'.

\footnotetext{
22 Ibid, p. 15

23 Samatar (1997), p. 701

${ }^{24}$ Lewis (1988), p. 209

${ }^{25}$ Harper (2012), p. 53
} 
As Richard Dowden rightly observes, the post-independence era saw many African leaders preach against tribalism in the cause of national unity. ${ }^{27}$ Aware of the ubiquitous influence of ethnicity on the political and constitutional processes, practically all African constitutions contain provisions proscribing the negative utility of tribal associations as part of their fundamental human rights. For example, the Nigerian Constitution states that national integration shall be actively encouraged, whilst discrimination on the grounds of place of origin, ethnic or linguistic association or ties shall be prohibited. ${ }^{28}$ Whilst such provisions are inherently rational, the new cornerstone of Somali official policy went one step further; Barre's means of discouraging discriminatory clan alliances, was to outlaw them altogether deeming them an anathema to the socialist revolution.

In a bid to sweep away 'old-fashioned' clannish culture from civil society, Somalis caught engaging in traditional clan activities were subject to fine and/or imprisonment. ${ }^{29}$ Somalis were forbidden to refer to each other in terms of their clan, instructed instead to address one another as jaale, which meant 'comrade' or 'friend'. ${ }^{30}$ In the interest of this new modern state, jaale launched into general currency with official blessings to replace the traditional, polite term of address 'cousin' (ina'adeer), which was now considered undesirable because of its kinship connotations. ${ }^{31}$ Even the shift from 'what is your clan?' to 'what is your ex-clan?' did little to appease Barre or the informers who reported qalibilists to the government.

Through his policies of 'Scientific Socialism', Barre sought to transform Somalia into a contemporary nation-state. Whilst his intentions may seem reasonable and even justifiable, the execution of this Marxist ideology was wholly inadequate by any standard of effective leadership. In this crucial attack on clans, Barre undermined the historical prevalence of nomadic Somali culture and, in doing so, failed to account for the most crucial element in any leadership transaction: the followers.

\footnotetext{
${ }^{26}$ Lewis, I.M. (2002), A Modern History of the Somali: Nation and State in the Horn of Africa, Eastern African Studies (Ohio University Press) 4, Revised edition, p. 22

27 Dowden, Richard (2009), Africa: Altered States, Ordinary Miracles (Portobello Books)

${ }^{28}$ See Nigerian Constitution Section 15, Subsection 2

${ }^{29}$ Harper (2012), p. 54

${ }^{30}$ Harper (2012), p. 54

${ }^{31}$ Lewis (1988), p. 210
} 


\section{Leader-Follower Influence Exchange}

Celebrating the $5^{\text {th }}$ year of the coup, now conveniently dubbed a 'revolution', The Ministry of Information and National Guidance published a series of publications to present a snapshot view of different facets of the country's 'progress'. As expected, the documents are filled with smiling photographs and glowing paragraphs about the rebirth of the nation-state and the close working relationship between the Somali people and its Barre-led Government. Yet this propaganda-laden narrative conceals a more sinister reality. Barre's determination to keep to the letter and spirit of his socialist declaration resulted in the use of material resources to exert power over the Somali people. In circumventing their will, Barre disregarded the relational nature of effective leadership and the overriding importance of mutuality.

It is necessary to stress the incompatibility of Barre's socialist declaration as it plays an introductory role to a phenomenon that so many confuse for Leadership: Power. As Northouse notes, the concept of power is related to leadership because it is integral to the influence process. ${ }^{32}$ Therefore, in discussions of leadership, it is not unusual for leaders to be described as individuals who dominate others. Yet, when examined closely, it soon becomes clear that power is a rather complex construct with many of its components far removed from that of leadership.

It is worth focusing on Northouse's construction on Personal and Position power which is based on French and Raven's observation of the five common and important bases of power. ${ }^{33}$ Personal power will be discussed further along in the discussion so it suffices to say here that, Position power is said to consist of Coercive, Reward and Legitimate power. Coercive power is derived from the capacity to punish others, Reward power, from the capacity to reward others and Legitimate power, through occupying a formal position. Position power is therefore, the influence capacity a leader derives from having a higher status that the followers.

In such instances, power is conceptualized as a tool that leaders use to achieve their own ends as can be seen by Dahl's highly acclaimed and often-cited definition:

\footnotetext{
32 Northouse, Peter G. (2013), Leadership: Theory and Practice, Sixth Edition (Western University Press), p. 9

${ }^{33}$ Northhouse (2013), p. 10 and, French Jr, J.R. \& Raven, B. (1962), 'The Bases of Social Power', in D. Cartwright, ed., Group Dynamics: Research and Theory (Harper \& Row, New York), pp. 259-269
} 
'Power is best understood as the ability of A to get B to do what B otherwise would not do'. 34

As Barnett and Duvall explain, Dahl's concept has three defining features: (1) There is intentionality on the part of Actor A, (2) there must be a conflict of desires, to the extent that B now feels compelled to alter its behaviour, (3) A is successful because it has material resources at its disposal that lead B to alter its actions. ${ }^{35}$ This cannot be better demonstrated than through Somalia under Barre's regime.

On 21 October 1969, Barre took power amid genuine excitement by Somalis who had grown weary of the corruption, partiality and injustice perpetuated by their elected representatives. ${ }^{36}$ Now, decades later, observers regularly equate Barre's rule to a brutal dictatorship. The United Nations Development Programme stated that 'the 21-year regime of Siad Barre had one of the worst human rights records in Africa'. ${ }^{37}$ This is perhaps unsurprising as September 1970 saw the introduction of the National Security Law No. 54, which granted Barre's National Security Service (NSS) the power to arrest and detain indefinitely those who expressed critical views of the government. Under Article 1, capital punishment was mandatory for anyone convicted of 'acts against the independence, unity or security of the State'. The decision to proudly mention clan affiliations would no doubt threaten 'national unity', giving the NSS the power to arrest and engage in the inhumane acts of torture as reported by Amnesty International. ${ }^{38} \mathrm{~A}$ report from 1991 stated that an elder from the dominant Hawiya clan, of central and southern Somalia, urged Siad to resign. Siad's response was: 'When I came to Mogadishu there was one road built by the Italians. If you try to force me to stand down, I will leave the city as I found it. I came to power with a gun; only a gun can make me go' ${ }^{39}$

This sort of power necessarily entails influencing others to do something against their will, yet as Northouse points out, this eliminates perhaps the most crucial part of leadership; the wants and needs of followers. ${ }^{40}$ As Barbara Kellerman notes in her 2008 study of followership, the 'follower' designation has historically been considered an insult, and shunned by many leadership

\footnotetext{
${ }^{34}$ Dahl, Robert A. (1957), 'The Concept of Power', Behavioral Science, 2:3, pp.201-215, at pp. 202-203

35 Barnett, Michael and Duvall, Raymond (2005), 'Power in International Politics', International Organization, Vol. 59, No. 1, pp. 39-75, p. 49

${ }^{36}$ Bulhan, Hussein Abdilahi (2008), Politics of Cain: One Hundred Years of Crises in Somali Politics and Society (Tayosan International Publishing), p. 168

${ }^{37}$ UNDP, Human Development Report 2001-Somalia (New York), 2001, p. 42

${ }^{38}$ Amnesty International, Torture in the Eighties (Bristol, England: Pitman Press, 1984), p. 127

${ }^{39}$ Greenfield, Richard, 'Siad's Sad Legacy', Africa Report, 1991

${ }^{40}$ See, Northouse (2013)
} 
scholars. ${ }^{41}$ This is a rather archaic way of thinking, one which reflects the dynamics of decades past in which leaders were directive and active whilst followers were submissive and passive. In actual fact, leadership is a group process involving the art of inducing compliance, not forcing compliance. ${ }^{42} \mathrm{As}$ Adair rightly observed, 'you are not a leader until your appointment has been ratified in hearts and minds of followers'. ${ }^{43}$ So in order for effective leadership to occur, there must be an unequivocal acceptance of a leader's assertion of influence. This is the critical element of leadership often referred to as 'mutuality' whereby followers are willing to work with leaders to attain a common unified goal.

The widespread use of 'Jaale' on the streets of Mogadishu should not be confused for acceptance of this new system. Barre built a formidable cult of personality, re-creating himself as 'Victorious Leader' (Guulwaadde) and the father of Somalia, so the fact that radio newscasts and public appearances would begin with a song dedicated to "Our Father, the Father of Knowledge." should also not be seen as evidence of support amongst the follower base. ${ }^{44}$ Follower sentiment can however be deduced from records showing that in the eight months between May 1988 and January 1989, an estimated 300,000 - 500,000 Somali refugees had arrived in eastern Ethiopia from northern Somalia, sometimes at the rate of 4,000 a day'. 45

Whilst the act of nullifying the supposedly primitive, pre-colonial identification system seemed easy enough, this denunciation consequently posed the problem of a new method of identification. Though Barre's unanimous decision to outlaw clans controlled behaviour, it did so with brutal and ruthless force, without in any way altering mind-sets and belief systems of the common Somali.

Upon the declaration of scientific socialism, Barre did, however, receive a reward of ample weapons from the Soviets. This is perhaps an indication that his allegiance resided in external forces and not his own. ${ }^{46}$ As his power waned later in his rule; he came to rely heavily on his own clan for support, proving his

\footnotetext{
${ }^{41}$ Kellerman, Barbara (2008), Followership: How Followers Are Creating Change and Changing Leaders (Harvard Business Press)

${ }^{42}$ Bass, Bernard M. (1990), 'From Transactional to Transformational Leadership: Learning to Share the Vision', Organizational Dynamics, Vol 18(3), p.19-31, also see Burns, James MacGregor (1978), Leadership (New York: Harper \& Row)

${ }^{43}$ Adair, John (2003), The Inspirational Leader: How to Motivate, Encourage and Achieve Success (Kogan Page Limited)

${ }^{44}$ Ahmed and Green (1999), p. 117 See also, Brown (1993), p. 13

${ }^{45}$ Gersony, Robert (1989) Why Somalis Flee: Synthesis of Accounts of Conflict Experience in Northern Somalia by Somali Refugees, Displaced Persons and Others, Bureau for Refugee Programs, Department of State, p. 1

${ }^{46}$ Perlez (1992)
} 
proficiency in the discriminatory game of clan politics. ${ }^{47}$ Engaging in age-old tactics of divide and rule, Barre's policies inversely solidified clan ties while hoarding power in Mogadishu. With ideologies increasingly beginning to resemble cult personalities, it has been suggested that 'Scientific Siadism' might be an appropriate description of the Somali experience under Barre's regime; a regime which, as one can say with the benefit of hindsight, was undoubtedly doomed to fail. ${ }^{48}$

\section{Outcome}

On the evening of 26 January 1991 Mohamed Siad Barre was forcibly removed from government as he fled Mogadishu for his clan homelands. Confronted by a vengeful Somali militia, and alarmed by disagreements between his own family and supporters, Barre eventually fled to Kenya. ${ }^{49}$ It was the end of his 21-year rule in Somalia, which had started as Socialist experimentation and disintegrated into a regime of brutal repression. Challenges to Barre's leadership were almost invariably organisationally clan-based; showing the lasting power of the social institution he tried to destroy. As Greenfield notes, it must be stressed that the clan-based civil war that followed Barre's overthrow was not mindless chaos, but a follower revolt and a violent reassertion of traditional Somali values. ${ }^{50}$

It would be rather partial not to at least briefly mention that Barre facilitated a number of positive reforms in the country, including the advancement of women's rights, the expansion of access to education and implementation of the first written Somali language, but the rejection of clans would prove to obscure these successes and prove to be his undoing. ${ }^{51}$ As Machiavelli notes:

There is nothing more difficult to plan, more doubtful of success, nor more dangerous to manage than the creation of a new system. For the initiator has the enmity of all who would profit by the preservation of the old system and merely lukewarm defenders in those who would gain by the new one..$^{52}$

'Barrier to Somali Unity: Clan Rivalry' was the title of Perlez's 1992 article. ${ }^{53}$ Whilst this may appear to tie in to this discussion, this article does not make the

\footnotetext{
47 Greenfield, Richard, 'An Embattled Barre', Africa Report, 1987

${ }^{48}$ Lewis (1988), p. 225

${ }^{49}$ Greenfield, Richard, 'Obituary: Mohamed Said Barre', The Independent, January 1995

${ }^{50}$ Greenfield, Richard, 'Siad's Sad Legacy', Africa Report, 1991, p. 18

${ }^{51}$ Forti, Daniel R. (2011), A Pocket of Stability: Understanding Somaliland, Occasional Paper Series: Issue 2, p. 15

52 Machiavelli, The Prince, 1513

${ }^{53}$ Perlez (1992)
} 
common mistake of placing clan rivalry as the foundations of the splintered state seen today. The increasing rate of intermarriages between Somali clans shows that there was, and indeed still is, scope for building national unity. ${ }^{54}$ Yet Barre's imported forms of governance proved instrumental to sowing seeds of discord and destruction.

That Somalia has been reduced to numerous civil wars results from a complex and incomplete leader-follower interaction by a leader who failed to account for the omnipotence of the clan structure, a phenomenon which remains stronger and more durable than any form of central authority. Speaking to Africa Watch about the reconciliation in Somalia, Yusef remarked that he and other Somalis were 'waiting to be mobilized into the kind of action that will enable them to play a serious role in getting out of the quagmire'. ${ }^{55}$ In other words, they are waiting for leadership; the kind remarkably different from the version Barre adopted in 1969.

\section{Botswana: Seretse Khama, Personal Power and Unity by consensus.}

'Botswana is hardly a household word, even in Africa. Bedevilled by many of the problems which beset today's developing countries... the crisis will come, however, as the honeymoon period of independence expires'.

- Richard 0. Ulin, 1976.56

Botswana's bid for independence was met by distinctly gloomy forecasts of their future. With dry and arid land, and a poor, undereducated and fragmented populace, prospects for success in the global realm was markedly low. However, fortified with the benefit of hindsight, it can now be seen that a number of bricks laid during this period of profound uncertainty paved the way for what would become a sovereign entity with a respected voice in today's regional affairs. That Botswana today is a shining example of national unity, owes much to the

\footnotetext{
${ }^{54}$ Musau, Stephen (2013), Clans' and clannism's control over weak political institution, in ITPCM International Commentary, Somalia Clan and State Politics, pp.13-18 at p. 14

${ }^{55} \mathrm{Al}$-Azhari, Yusuf Omar (1994) A message for forgiveness for all Somali factions, Crisis Management and the Politics of Reconciliation in Somalia: Statements from the Uppsala Forum, 17-19 January 1994, pp. 71-72, p. 71

${ }^{56}$ Ulin, Richard O. (1976), 'African Leadership: National Goals and the Values of Botswana University Students', Comparative Education, Volume 12, Issue 2, pp. 145-155, p. 145
} 
determination of 'a man who could easily have chosen to live quietly in Serowe amongst his own people, whilst looking after the cattle that he so adored'.57

\section{The Situation}

As touched upon by Harper in a previous quotation, Botswana is the other African country often dubbed as homogenous; this is often used to rationalise their cohesive front in the midst of racially fragmented states. Yet, as in the case of Somalia, this is a rather misleading observation. In actual fact, in the immediate post-colonial period, Botswana was a traditional society with a fairly scattered, and ethnically diverse population. ${ }^{58}$ Apart from the Setswana-speaking people in most of the central, east and southern parts of the country, the different ethnicities burgeoning across the Southern African state include the Kalanga-speaking peoples of the north and north east districts, the Basubiya, Bateti, Baherero, Bayei people in the north and north-west of the country, and the more detached people of San and Khoe ethnicity. ${ }^{59}$ This non-exhaustive list of ethnic groupings does much to discredit the idea that national unity had always prevailed amongst the people of Botswana.

Reality however shows that the promotion of national unity was a task actively confronted by the architects of Botswana's independence who were very much aware of the cultural and racial difference inherent the country's population. Major tribes, particularly the Kalanga, historically displayed strong separatist tendencies as their subtle moves towards nationalism continued to threaten to the stability of Botswana. ${ }^{60}$ Acknowledging this in his address to the African Advisory Council in 1958, Tshekedi Khama pondered on the kind of nation an independent Botswana would be, given the strong 'separate tribal element'. He called for the 'need to fashion a common citizenship so as to create a bond between race and race and tribe and tribe'.61 This was the situation; this was the call for leader emergence.

\section{Leader Emergence}

This call would be answered by his nephew, Seretse Khama, heir apparent to the chieftainship of the Bamangwato. Born to a royal Serowe family, Khama stood to

\footnotetext{
${ }^{57}$ Henderson, Willie (1990),' Seretse Khama: A Personal Appreciation', African Affairs, Vol. 89, No. 354, pp. 27-56, p. 27

${ }^{58}$ Khama, H.E. Sir Seretse (1970), Botswana - a Developing Democracy in Southern Africa, Scandinavian Institute of African Studies (Uppsala) at p. 6

${ }^{59}$ Brothers, Hermans, and Nteta (1993), p. 376

${ }^{60}$ Gillett, Simon (1973). 'The Survival of Chieftaincy in Botswana', African Affairs, Vol. 72, No. 287, pp. 179-185

${ }^{61}$ Brothers, Hermans, and Nteta (1993), p. 380
} 
benefit from the divine right of kings; the political and religious doctrine of royal and political legitimacy. Whilst this doctrine necessarily entails that a monarch is subject to no earthly authority, Khama's claim to his birth right was directly challenged by his decision to marry an English woman in $1948 .{ }^{62}$ Whilst this controversy has little relevance to the focus of this discussion, it remains crucial to note that Khama's decision to marry Ruth resulted in him renouncing all claims to his Chieftaincy before an assembly of 7,000 persons. ${ }^{63}$ Khama subsequently became leader of the Botswana Democratic Party (BDP) which went on to become the dominant political force since independence. Without the option of claiming authority though traditional means, Khama was duty-bound to campaign and stand for elections, participating in politics as an ordinary Tswana man. It is therefore crucial to note that Khama's meteoric rise to prominence was emergent and not appointed leadership. ${ }^{64}$ This point is revisited when considering mutuality between Khama and the people of Botswana as his leadership was not rooted in his position, but his ability to meet the needs of the ordinary people.

\section{Leadership Moment}

A Presidential Task Group under Quett Masire released a publication presenting Botswana's long term vision for the year 2016; their 50 year anniversary as an independent nation. ${ }^{65}$ The promulgated development plans were based on Khama's identification of four national principles; Democracy, Development, Self-Reliance and Unity. Now, after half-a-century of independence, it is useful to reflect on Khama's approach to instituting the latter principle of 'Unity' as this is where real, enduring leadership occurred.

Khama understood that Botswana could not rest on the formal institutions of representative democracy alone. Whilst noting the importance of the western parliamentary system, Khama went a step further by considering how ordinary Tswana people might be able to exert direct influence in Botswana's new participatory democracy. In a bid to create a strong central government, whilst concurrently showing due respect for tribal traditions and institutions, Khama took the decision that the custom of chieftainship would continue to play an integral role in the running of the affairs of the country. As Holm notes, according to custom, the Tswana chief is the personification of any given tribe; they are a mouthpiece used to project the communal decisions, and voice the mutual

\footnotetext{
${ }^{62}$ Frank, Lawrence (1981), 'Khama and Jonathan: Leadership Strategies in Contemporary Southern Africa', The Journal of Developing Areas, Vol. 15, No. 2, pp. 173-198, p. 175

63 Frank (1981), p. 182

${ }^{64}$ Northouse (2013), p. 8

65 Vision 2016: Towards Prosperity for All, Presidential Task Force, 1996
} 
concerns, of different factions of society. ${ }^{66} \mathrm{In}$ a commendable show of respect, Khama showed no bitterness towards being forced to denounce his own chieftaincy title; he did not belittle the role of the chief to merely an advisory capacity, a tactic frequently employed during the colonial era. Instead, he infused their role into the overall development project allowing them to operate in seamless harmony with the central government.

Warren Bennis asserted that 'Vision' was one of the characteristics of effective leadership, Khama certainly met this criteria. ${ }^{67} \mathrm{He}$ understood that active loyalty and cooperation of the ordinary tribesman was essential to the country's collective development. In transforming the role of the chief to autonomous district authorities, Khama could foresee the need to adapt and decentralise the western conceptualisation of governance to meet unique demands of Botswana. In allowing chiefs to continue to play their role as custodians of Tswana culture, Khama managed to remarkably use tribal loyalties to promote stability, and a mutual sense of purpose amongst the people of Botswana during a time in which they were surrounded by states, undergoing a period of hostility, fragmentation and racial division.

\section{The Leader-Follower Influence Exchange}

Socialism was a philosophy which quickly spread across Africa on the onset of independence; leader after leader, including Somalia's Barre, formally stated that it would be their guiding ideology going forward. Yet, Khama expressed his doubt in the applicability of this principle, underlining that even if qualified by the adjective 'African', socialism can have little meaning for the majority of Tswana people. ${ }^{68}$ Botswana's aforementioned development plans were not merely imported slogans, as we saw in the case of Scientific Socialism, but were presented to the Tswana people as vivid illustrations of what already existed in all facets of their society. In promoting social harmony, or Kagisano, Khama opted for values and ideologies deeply rooted in existing cultures and traditions which cut across ethnic lines. Choosing to encapsulate guiding principles in ideas readily comprehensible to the varied people of Botswana, Khama established mutuality. He not only promulgated a common goal, but carefully laid the foundations of the sort of nationalism which could incorporate wide-ranging interpretations of living long and living well.

It is not worth spending a considerable amount of time debating as to whether or not Khama had followers. When Khama returned to the Bamangwato capital

\footnotetext{
${ }^{66}$ Holm, John D. (1974), Dimension of Mass Involvement in Botswana Politics: A Test of Alternative Theories (Beverly Hills: Sage Publications), p. 16

${ }^{67}$ Bennis, Warren (1989) Why Leaders Can't Lead (Lossey Bass, San Francisco)

${ }^{68}$ Khama (1970), p. 5
} 
after his years in exile, he was reportedly greeted at the airfield by thousands of adoring men, women and children. ${ }^{69}$ Though some threw hats in the air, and others flung themselves to the ground, one should be careful to not mistake this for the same cult of personality observed with Barre. One journalist reported that the former chief had virtually leaned over backwards to discourage demonstrations, whilst Nyerere noted that 'Seretse Khama has not at any time allowed himself to be caught up in the surface glamour, excitement, and inevitable privilege of his position as Head of State and Head of Government'.70 Khama understood that leadership transcends far beyond him or his charisma; it is essentially rooted in his ability to respond to the collective will of the people.

'You do not achieve development by forcing people in directions they do not want to go for reasons they do not understand [...] The President and Parliament can govern effectively only with the consent and active participation of the people. The institutional framework has changed, but the fundamental principle, that decisions which affect the lives of the people must have the consent of the people, has not been modified'.

- Seretse Khama, 1969. ${ }^{71}$

Khama emphasised democracy as an ideological norm in a bid the vehemently repudiate the popular idea that democracy has no place in Africa. ${ }^{72}$ Indeed democracy was not new to Botswana as evidenced by the saying, 'Kgosi ke kgosi ka batho' ('A chief is a chief by the people'). ${ }^{73}$ Henderson noted that Khama's behaviour stood in sharp contrast to the behaviour of those aristocratic members steeped in the privileges of kingship. ${ }^{74}$ Poor villagers within the former Bechuanaland Protectorate were not accustomed to members of the nobility exchanging jokes and handshakes. This is perhaps due to the circumstances of his emergence which was touched upon earlier; Khama's political campaigns, and willingness to subject himself and his ideas to the popular vote, inspired a sense of loyalty amongst followers who were captivated by his personal approach and attributes. As Parson noted, Khama wore many hats:

1. For the peasants, he is a chief.

2. For the small group of educated Africans, he is one of them.

\footnotetext{
${ }^{69}$ Frank (1981), p. 182

${ }^{70}$ Frank (1981), p. 182, and President Julius Nyerere, Forward in From the Frontline: Speeches of Sir Seretse Khama, Edited by Carter, Gwendolen M. and Morgan, E. Philip (1980),

(Rex Collings, London), pp. ix-xiv, p.xiv

7150 Botswana Democratic Party, Election Manifesto 1969, p. 11

${ }^{72}$ Frank (1981), at pp. 190-191

73 Khama (1970), p. 7

${ }^{74}$ Henderson (1990), p. 38
} 
3. For the large cattle owners, he is one of them.

4. For the chiefs, he is one of them.

5. For the Europeans, by dress, language, behaviour and experience, he has much in common with them. ${ }^{75}$

This brings us to Northouse's conception of Personal power. It is clear to see that Khama possessed the final two of French and Ravens' power bases, Expert power and more, visible in this case, Referent power. Expert power is based on follower's perception of the leader's competence whilst Referent power is based on the follower's identification and liking for the leader. ${ }^{76}$ The allegory of the "omniscient leader" effectively disempowers followers, but Grint's Process approach to leadership suggests that when a situation arises, a leader cannot emerge without the permission of the group. ${ }^{77}$

Khama understood that in order to promote national unity, he needed to engage in transformational leadership. Burns defines this leadership approach as one that causes change in individuals and social systems. ${ }^{78}$ Endorsed in its purest form, transformational leadership unites the follower's sense of identity and self to the mission and the collective identity of the organisation, or in this case, the nation. Khama understood the importance of all citizens identifying with government goals and engaged, farmers, businessmen, and housewives alike to equally champion the national cause in their own capacity.

This crucially implies that effective leadership eliminates the exercise of coercive Position power since great significance is attributed to the followers' desires. On the basis of this, one can try to reconceptualise Dahl's popular definition: Leadership is best understood as the ability of A to get B to trust and accept A's assertion of influence, so that A can legitimately work towards achieving a common goal on behalf of $B$. In this model, the power of leaders is a consequence of the actions of followers rather than the cause of it'. ${ }^{79}$

\section{Outcome}

Khama had his faults and was open to criticism, yet when it comes to the promotion of national unity, it is difficult to question his judgement. In

\footnotetext{
${ }^{75}$ See, Parson, Jack (1990), 'Succession to High Office in Botswana: three case studies'. Monographs in International Studies, Africa Series No. 54, Athens (Ohio: Ohio University Center for International Studies), pp. 335-340

${ }^{76}$ Northouse (2013) at p.10 and, French and Raven (1962), pp. 259-269

77 See, Grint, Keith (2005), Leadership: Limits and Possibilities (Palgrave Macmillan), at pp. 100137

${ }^{78}$ See, Burns (1978)

${ }^{79}$ See, Grint (2005), pp. 100-137
} 
encouraging a communal sense of nationalism, the challenge that leaders face will always be that of framing laws which are sensitive enough to outlaw divisive and unnecessary distinctions whilst permitting and supporting positive distinctions. ${ }^{80}$ Where Barre failed in this regard, Khama thrived. In his Party manifesto, Khama championed laws against discrimination on the basis of tribe, as one would expect. Yet, rather tactically, in the same breath, he also opposed any 'laws which would destroy any communal associations or bands based on such common interest as language or culture where those associations or bands do not undermine the unity and progress of the state'. ${ }^{81}$

Khama's awareness and appreciation of the multi-ethnic nature of Botswana's population, enabled him to carefully craft the institutions necessary to manage and guide Botswana's national development. As Anderson observed, despite all his preoccupation with great issues at home and abroad, like most Batswana, Khama was a farmer under the skin. ${ }^{82}$ This fact, coupled with his mindfulness of the key components of effective leadership enabled him to steer people towards the mutual and clearly identifiable goal of Kagisano.

'His quiet sense of duty is an example to all, and is, I believe, universally acknowledged. I am honoured to pay tribute to President Seretse Khama, an African leader who brings honour to our continent'.

- Julius Nyerere, 1980.83

\section{Somaliland: Clan Elders and the Foundations of Effective leadership}

It is ironic that the region that was largely left alone by foreign power, and received very little outside help, is one of the most stable and certainly the most democratic, of all territories in the Horn of Africa. ${ }^{84}$ Perhaps the best indicator of Barre's failed attempt at shoring up national unity came when the North of the country broke away in 1991, declaring itself the independent republic of Somaliland. Yet Somaliland does more than indicate Barre' ineffective leadership, it also supports the conclusions drawn from Botswana by underscoring the

\footnotetext{
80 Fombad, Charles Manga (2004), 'The Constitutional Protection against Discrimination in Botswana', The International and Comparative Law Quarterly, Vol. 53, No. 1, pp. 139-170.

${ }^{81}$ Bechuanaland Democratic Party Election Manifesto, in Macartney, W J A, ed., Readings in Boleswa Government

82 Anderson, D. A. (1980), President Sir Seretse Khama - a personal view, in From the Frontline: Speeches of Sir Seretse Khama, Edited by Carter, Gwendolen M. and Morgan, E. Philip (1980)

(Rex Collings, London), pp. xv-xxi, p.xx

82 President Julius Nyerere (1980), pp. ix-xiv, p. xiv

${ }^{84}$ Harper (2012), p. 12
} 
undeniable role mutuality should play in any leadership discussion. Somaliland is another example of the development prospects of a people who are able to live well and live long together under responsive leadership. Whilst one must be careful not to exaggerate their success, it is equally important to note that by 2006, Somaliland could boast a popularly elected government, a growing civil society, a commonly endorsed constitution, and a political system with democratic credentials to rival any in the region and most Muslim states. ${ }^{85} \mathrm{As}$ will be shown, an inordinate amount of lessons can be drawn from the Somaliland experience; lessons which all go to prove that the quotation above is not as 'ironic' as the above quotation suggests.

What is perhaps most crucial to note is that whilst the formation of Somaliland was led by the Isaaq-clan-dominated Somali National Movement (SNM), a number of different clans still exist within this system; harmoniously. The heroes of this narrative will almost certainly be the clan elders, the traditional leaders who formed the bedrock of Somali society. As Minale notes, in promoting unity and stabilizing the development of Somaliland, the clan elders went above their historically allotted roles, thus rising or emerging to new, redefined leadership positions on the basis of the situation and task at hand. ${ }^{86}$

It remains necessary to look at specific instances of leadership in order to efficiently interrogate its effectiveness; noting that the situation under consideration is identical to that of Botswana and Somalia - the need to shore up national unity.

In May 1991, the SNM gathered traditional elders representing all northern clans to hold talks in Berbera and in doing so, called upon the most significant element of the Somali social institution, the Shir. ${ }^{87}$ Traditionally Shirs were the facilities by which major community decisions would be discussed and debated, including those related to conflict resolution. When Somaliland's traditional leaders and SNM senior officials began to lay the foundation for the creation of a new, united nation, the Shir was the logical starting point. With solid foundational groundings in Somali society, elders were empowered to invoke clan affiliations, end violence and to establish a rapport between warring factions. These conferences signified a rare blend of Western-styled governance institutions and traditional Somali structures; they reduced the tensions between clans, restored trust, and encouraged harmonious relations between communities. ${ }^{88}$

\footnotetext{
85 Bradbury, Mark (2008), Becoming Somaliland, African Issues (James Currey, Oxford), p. 1

${ }^{86}$ Minale, Gedamu Kalewongel (2013), 'How did Somaliland emerge as a stable and peaceful polity?', in ITPCM International Commentary, Somalia Clan and State Politics, pp.29-34, p. 30

${ }^{87}$ Forti (2011), p. 18

${ }^{88}$ Forti (2011), p. 18
} 
Superseding their traditional clan responsibilities, these "politically active clan elders," unmistakably emerged into a formidable army of leaders. ${ }^{89}$ Unlike the tribal chiefs in many African societies, elders in Somaliland are 'chosen by virtue of their personal attributes such as expertise in the political arts of compromise and persuasion, powers of oratory, skill as a poet, religious knowledge, piety, wealth, generosity, courage and reputations for fairness'. ${ }^{90}$ This merit-based system denotes that not all old men are elders, nor are all elders aged. This speaks to the earlier conclusion of the fundamentality of Referent power with regards to effective and durable leadership. Followers are an indistinguishable component of the leadership equation; their identification with a leader and belief in their competency, will always be the difference between momentary pacification and sustainable change.

It is imperative to note that traditional leaders of this kind can be found in Somalia as well as Somaliland. Both states were confronted with the same need to promote a national project that far surpassed the needs or grievances of a particular clan. Yet crucially, in Barre's supposedly sound opinion, this form of traditional practice was not only considered irrelevant to conflict resolution but an outright violation of state authority. ${ }^{91}$ Conversely, through the space provided by the SNM, clan elders embarked on a peace-building endeavour aimed at resolving all major outstanding issues between communities across the country.

Somaliland, illegitimate in the eyes of the world, has arguably emerged from the ashes with phoenix-like activity. ${ }^{92}$ Whilst far from perfect, the country's innumerate achievements cannot be overlooked. It can be argued that Somaliland's political isolation rather helped her domestically. Limited interaction with external forces afforded Somaliland the liberty to independently craft a representative system which was suited to the values and needs of its people. According to Bradbury, 'uniquely in Africa this has involved the incorporations of traditional institutions and practices into the system of governance'. ${ }^{93}$ Bradbury's use of 'unique' is questionable as the exact same model and exceptional outcome was registered with Khama in Botswana.

The renewal of societal cohesion in Somaliland does much to undermine the misinformed conclusion that Somalis are incapable of governing themselves. It

\footnotetext{
${ }^{89}$ Minale (2013), pp. 29-34, p. 30

${ }^{90}$ Ahmed and Green (1999), p. 123

91 Doornbos, Martin and Markakis, John (1994), 'Society and state in crisis: What went wrong in Somalia?', in Crisis Management and the Politics of Reconciliation in Somalia: Statements from the Uppsala Forum, 17-19 January 1994.

92 Bradbury (2008), p. 7

93 Ibid, p. 7
} 
is possible that those engaged in each of Somalia's fourteen, failed, internationally sponsored peace conferences may be missing the point. The issue Somalia faces is not merely the inability to 'get along'. The case of Somaliland reaffirms the earlier argument that the problem is not, and has never been, clans, for the clan is not a stable entity; it is dynamic, infinitely adaptable and constantly being remoulded by the political situation in the country. ${ }^{94}$ Whilst Somaliland bears witness to the adaptable nature of clan structures, it also underscores the argument that Somalia has suffered from unaccountable leadership. Leadership provides, authentic solutions to indigenous issues; in responding to varied needs, a common goal must be put on a pedestal, thus encouraging traditional systems of conflict management and communal development.

\section{Conclusion}

Though this study managed to bypass the topic of diamonds, critics of the decision to compare Somalia and Botswana may still put forward the existence of clans and the unique complexity of Somalia as a means of discrediting any comparative analysis on these respective nations. Yet, the intention of this article was to bring such arguments to naught through using the case of Somaliland to demonstrate that Somalia and Botswana's ability, or indeed inability, to successfully build national unity, is a direct result of the effectiveness of their leaders.

Barre's key oversight was the failure to appreciate the numerous differences between Somali society and the common characteristics of the contemporary nation-state, that is, the unitary and highly centralized system of rule. A venture into the nomadic, pastoral life of Somalis reveals that there were no strong material, political or social needs for a defined Somali nation-state. ${ }^{95}$ As Lewis explains, a hierarchical pattern of authority is foreign to the pastoral Somali society who already had an established process of decision-making. ${ }^{96}$ The decision to 'keep up appearances' with western governance systems introduced alien concepts and bolstered an elite minority of western-educated Somalis; thus weakening Somalia's customary authority founded on widespread participation and consensus.

The assessment of Botswana's development plans offers a good indication of the potential of institutions that have been adapted and re-appropriated by the local political culture. It is within this framework that one can appreciate the

\footnotetext{
${ }^{94}$ Harper (2012), p. 11

${ }^{95}$ Harper (2012), p. 31

${ }^{96}$ Lewis, quoted in Harper (2012), p. 22
} 
institutional experiences of Somaliland in which traditional forms of governance were tentatively absorbed within western models. ${ }^{97}$

One of the principal missions has been to dispel the idea that African tradition, is by nature, anti-development. The assessment of the diverse societies of Botswana, Somalia, and Somaliland repudiates the tribal explanation of civil wars and political fragmentation in Africa. In pursuit of this goal, this article has revealed the remarkable effects of leaders who possess the determination, foresight, and popular legitimacy to sell the group's agenda as the national interest. ${ }^{98}$ This task of managing the conversation and defining the scope of a new, collective project could not have fallen on more appropriate leaders than Botswana's first president, Seretse Khama, and the clan elders of Somaliland.

* Nancy Adimora is the Founding Editor of AFREADA, an African literary magazine.

\section{BIBLIOGRAPHY}

Adair, John (2003) The Inspirational Leader: How to Motivate, Encourage and Achieve Success (Kogan Page Limited)

Africa Watch Report (1990), 'SOMALIA, A Government at War With Its Own People, Testimonies About The Killings and The Conflict in the North', January

Ahmed, Ismail I and Reginald Herbold Green (1999) 'The heritage of war and state collapse in Somalia and Somaliland: local-level effects, external interventions and reconstruction', Third World Quarterly, Vol 20, No 1, pp. 113127

Al-Azhari, Yusuf Omar (1994) A message for forgiveness for all Somali factions, Crisis Management and the Politics of Reconciliation in Somalia: Statements from the Uppsala Forum, 17-19 January 1994.

Amnesty International (1984) Torture in the Eighties (Bristol: Pitman Press)

\footnotetext{
97 Gonnelli, Michele (2013) Clan and State Politics - Intro, in ITPCM International Commentary, Somalia Clan and State Politics, pp.8-12 at p. 9

98 For more, see Samatar, Abdi Ismail (1999), An African Miracle: State and Class Leadership and Colonial Legacy in Botswana Development (Heinemann Educational Books, U.S.)
} 
Anderson, D. A. (1980) 'President Sir Seretse Khama - a personal view', in Carter, Gwendolen M. and E. Philip Morgan, eds. (1980) From the Frontline: Speeches of Sir Seretse Kham (London: Rex Collings)

Barnett, Michael and Duvall, Raymond (2005) 'Power in International Politics', International Organization, Vol. 59, No. 1, Winter, pp. 39-75

Bass, Bernard M. (1990), 'From Transactional to Transformational Leadership: Learning to Share the Vision', Organizational Dynamics, Vol 18(3), pp.19-31

Bechuanaland Democratic Party Election Manifesto, in Macartney, W J A, ed., Readings in Boleswa Government

Bennis, Warren (1989), Why Leaders Can't Lead (San Francisco: Lossey Bass) Botswana Democratic Party, Election Manifesto 1969

Bradbury, Mark (2008), Becoming Somaliland, African Issues (Oxford: James Currey)

Brothers, Sue, Janet Hermans, and Doreen Nteta (1993), Botswana in The $21^{\text {st }}$ Century: Proceeding of a Symposium, Organised by The Botswana Society, October 18-21

Brown, Fraser (1993), 'Tragedy in Somalia: Clans, Colonisers, Superpowers, and the Cult of Personality', Origins, May

Bulhan, Hussein Abdilahi (2008), Politics of Cain: One Hundred Years of Crises in Somali Politics and Society (Tayosan International Publishing)

Burns, James MacGregor (1978), Leadership (New York: Harper \& Row)

Cassanelli, Lee V. (1982), The Shaping of Somali Society: Reconstructing the History of a Pastoral People, 1600 to 1900 (University of Pennsylvania Press)

Dahl, Robert A. (1957), The Concept of Power, Behavioral Science, 2:3, pp.201215

Doornbos, Martin and Markakis, John, Society and state in crisis: What went wrong in Somalia?, in Crisis Management and the Politics of Reconciliation in Somalia: Statements from the Uppsala Forum, 17-19 January 1994

Dowden, Richard (2009), Africa: Altered States, Ordinary Miracles (Portobello Books) 
Drysdale, John (1964), The Somali Dispute (London: Pall Mall Press)

Fombad, Charles Manga (2004), The Constitutional Protection against Discrimination in Botswana, The International and Comparative Law Quarterly, Vol. 53, No. 1 Jan., pp.139-170

Forti, Daniel R. (2001) A Pocket of Stability: Understanding Somaliland, Occasional Paper Series: Issue 2

Frank, Lawrence (1981), 'Khama and Jonathan: Leadership Strategies in Contemporary Southern Africa', The Journal of Developing Areas, Vol. 15, No. 2, pp. 173-98

French Jr, J.R. and Raven, B. (1962), 'The Bases of Social Power', in D. Cartwright, ed., Group Dynamics: Research and Theory (New York: Harper \& Row), pp. 259269

Gersony, Robert (1989), 'Why Somalis Flee: Synthesis of Accounts of Conflict Experience in Northern Somalia by Somali Refugees, Displaced Persons and Others', Bureau for Refugee Programs, Department of State, August

Gillett, Simon (1973), 'The Survival of Chieftaincy in Botswana', African Affairs, Vol. 72, No. 287 Apr., pp. 179-185

Gonnelli, Michele (2013), 'Clan and State Politics - Intro, in ITPCM International Commentary', Somalia Clan and State Politics, December

Greenfield, Richard (1987), 'An Embattled Barre', Africa Report, June 1987, pp. 65-69

Greenfield, Richard (1995), 'Obituary: Mohamed Said Barre', The Independent, $3^{\text {rd }}$ January 1995

Greenfield, Richard (1991), 'Siad's Sad Legacy', Africa Report, Vol 36, No 2, March-April, pp. 13-18

Grint, Keith (2005), Leadership: Limits and Possibilities (London: Palgrave Macmillan).

Harper, Mary (2012), Getting Somalia Wrong? Faith and War in a Shattered State, African Arguments (Zed Books) 
Henderson, Willie (1990), 'Seretse Khama: A Personal Appreciation', African Affairs, Vol. 89, No. 354 Jan., pp. 27-56

Holm, John D. (1987), 'Botswana: A Paternalistic Democracy', World Affairs, Vol. 150, No. 1, pp. 21-30

Holm, John D. (1974), Dimension of Mass Involvement in Botswana Politics: A Test of Alternative Theories (Beverly Hills: Sage Publications)

Kellerman, Barbara (2008), Followership: How Followers Are Creating Change and Changing Leaders (Boston: Harvard Business Press)

Khama, H.E. Sir Seretse (1970), Botswana - a Developing Democracy in Southern Africa, Scandinavian Institute of African Studies, Uppsala

Kotter, John (1990b), A force for change: How leadership differs from management (New York: Free Press)

Bennis, Warren and Burt Nanus (1985), Leadership: The strategies for taking charge (New York: Harper \& Row)

Lewis, I.M. (1988), A Modern History of Somalia: Nation and State in the Horn of Africa, Revised, updated and Expanded Edition (Boulder, Colo.: Westview Press)

Lewis, I.M. (2002), A Modern History of the Somali: Nation and State in the Horn of Africa, Eastern African Studies, Ohio University Press; 4, Revised edition

Lewis, I.M., quoted in Harper, Mary (2012), 'Getting Somalia Wrong? Faith and War in a Shattered State', African Arguments (London: Zed Books)

Lewis, I.M. (1981), Somali Culture, History, and Social Institutions: An Introductory Guide to the Somali Democratic Republic (London School of Economics \& Political Science)

Minale, Gedamu Kalewongel (2013), 'How did Somaliland emerge as a stable and peaceful polity?', in ITPCM International Commentary, Somalia Clan and State Politics, December 2013

Ministry of Information and National Guidance (1974), 'Somalia - Five Years of Revolutionary Progress', Mogadishu, 1 June 
Musau, Stephen (2013), 'Clans' and clannism's control over weak political institution', in ITPCM International Commentary, Somalia Clan and State Politics, December

Northouse, Peter G. (2013), Leadership: Theory and Practice, Sixth Edition (Western University Press)

Nyamnjoh, Francis B. (2002), 'Might and Rights: Chieftaincy and Democracy in Cameroon and Botswana', Paper Prepared for CODESRIA's $10^{\text {th }}$ Assembly on "African in the New Millennium", Kampala, Uganda, December 8-12, 2002

Nyerere, President Julius (1980), 'Forward', in Cater, Gwendolen and E. Philip Morgan (1980), From the Frontline: Speeches of Sir Seretse Khama (London: Rex Collings)

Odowa, Abdullahi M. (2013), 'What can current leaders in Somalia learn from their past history?', in ITPCM International Commentary, Somalia Clan and State Politics, December

Olonisakin, Funmi (2015) 'Reconceptualising Leadership for Effective Peacemaking in Africa', Strategic Review of Southern Africa, Vol. 37 No.1, May 2015, pp. $122-151$

Parson, Jack (1990), 'Succession to High Office in Botswana: three case studies', Monographs in International Studies, Africa Series No. 54 (Athens, Ohio: Ohio University Center for International Studies)

Perlez, Jane (1992), 'Barrier to Somali Unity: Clan Rivalry', The New York Times, August 30

Presidential Task Force (1996), Vision 2016: Towards Prosperity for All

Rost, Joseph C. (1991), Leadership for the Twenty-First Century (New York: Praeger)

Samatar, Abdi Ismail (1999), An African Miracle: State and Class Leadership and Colonial Legacy in Botswana Development (Heinemann Educational Books)

Samatar, Abdi Ismail (1997), 'Leadership and Ethnicity in the Making of African State Models: Botswana versus Somalia', Third World Quarterly, Vol. 18, No. 4 Sep., pp. 687-707 
Stogdill, Ralph M. (1948), 'Personal factors associated with leadership: A survey of the literature', Journal of Psychology, 25

Ulin, Richard 0. (1976), 'African Leadership: National Goals and the Values of Botswana University Students', Comparative Education, Volume 12, Issue 2, pp. 145-155

UNDP (2001), Human Development Report 2001-Somalia, New York 